\title{
WYBRANE PROBLEMY ZARZĄDZANIA FINANSAMI GOSPODARSTW DOMOWYCH W KRAJACH EUROPEJSKICH
}

\author{
Agnieszka Wiśniewska \\ Wydział Zarządzania i Ekonomiki Usług \\ Uniwersytet Szczeciński
}

\section{Streszczenie}

Gospodarstwa domowe charakteryzują się bardzo dużą różnorodnością w zakresie dysponowania swoimi środkami pieniężnymi. Jedne gospodarstwa domowe większość swojego dochodu przeznaczają na rzecz konsumpcji bieżącej, inne na regulację swoich zobowiązań, zaś kolejne na oszczędności i inwestycje. Zarządzanie finansami osobistymi (czyli finansami gospodarstw domowych), związane jest z podejmowaniem decyzji w zakresie dostępnego budżetu w taki sposób, aby zrealizowany był cel należący do gospodarstw domowych, czyli maksymalizacja zaspokojenia potrzeb. Niniejsze opracowanie dotyczy przede wszystkim decyzji finansowych w zakresie zadłużenia oraz oszczędności, a także ukazania różnic między nimi w poszczególnych krajach Europy. Celem jest wskazanie ram teoretycznych zagadnienia związanego z zarządzaniem finansami gospodarstw domowych. Za hipotezę przyjmuje się, iż im wyższy dochód rozporządzalny gospodarstw domowych w danym państwie, tym wyższy udział oszczędności w dochodzie. Dodatkowo, im bardziej zadłużone są gospodarstwa domowe w danym kraju europejskim, tym oszczędności są niższe i przyjmują wartości ujemne.

Słowa kluczowe: gospodarstwo domowe, zadłużenie, oszczędności.

JEL Class: D14, E21, H31. 


\section{WPROWADZENIE}

Współcześnie, w każdym kraju niezależnie od poziomu rozwoju społeczno-gospodarczego, gospodarstwa domowe zgłaszają zapotrzebowanie na różnego rodzaju dobra i usługi konsumpcyjne. Jednak, w dobie nieograniczonej dostępności do usług finansowych, coraz więcej jednostek stara się racjonalnie rozporządzać swoimi pieniędzmi - prócz korzystania z podstawowych instrumentów takich jak rachunek bankowy czy lokata oszczędnościowa, wybiera się bardziej zróżnicowane instrumenty finansowe. Zgłaszany popyt zależny jest od poziomu wiedzy danego gospodarstwa domowego, jego poziomu zamożności, ale także oferty prezentowanej przez różnorodne jednostki finansowe. Zarządzanie finansami osobistymi niezbędne jest do optymalizacji zarówno rozporządzalności budżetu, jak i wykorzystania dostępnych usług finansowych. Celem niniejszego opracowania jest wskazanie tego, jak gospodarstwa domowe w krajach europejskich zarządzają swoim budżetem, a także wskazanie różnic i podobieństw między nimi. Za hipotezę przyjmuje się twierdzenie, iż im wyższy dochód rozporządzalny gospodarstw domowych w danym państwie, tym wyższy udział oszczędności w dochodzie. Dodatkowo, im bardziej zadłużone są gospodarstwa domowe w danym kraju europejskim, tym oszczędności są niższe i przyjmują wartości ujemne. Metody badawcze wykorzystane w niniejszym opracowaniu to krytyczna analiza literatury oraz metody statystyczne (opracowanie wyników pochodzących z OECD).

\section{SPECYFIKA GOSPODARSTW DOMOWYCH I ZARZAZDZANIE FINANSAMI}

Nauka dotycząca finansów jest dziedziną bardzo szeroką, a w jej zakresie mieści się duża liczba podkategorii, takich jak np. finanse publiczne, finanse przedsiębiorstw, finanse globalne, finanse banków, a także finanse gospodarstw domowych. Samo pojęcie gospodarstwa domowego w literaturze przedmiotu jest opisane dość obszernie, jednak wskazać należy, iż nie ma jednej, precyzyjnej definicji tego pojęcia. Pałaszewska-Reindl określa gospodarstwo domowe jako mikrojednostkę, która wytwarza dochód, a następnie dokonuje jego podziału na różnego rodzaju cele [Pałaszewska-Reindl i Michna 1986: 34]. Samuelson zaś identyfikuje gospodarstwo domowe jako podstawowy podmiot gospodarczy, który to ma na celu zgłaszanie popytu na ryku dóbr i usług konsumpcyjnych [Samuelson i Nordhaus 2005: 564-565]. Światowy wskazuje zaś, że gospodarstwo domowe jest wspólnotą ludzi, którzy wspólnie żyją, łącząc wzajemne zamieszkiwanie, a także wspólne gospodarowanie, które to ma na celu realizację celów oraz potrzeb w zakresie konsumpcji [Światowy 2012: 57]. Wielokrotnie, $\mathrm{w}$ zasobach literatury, gospodarstwo domowe utożsamiane jest $\mathrm{z}$ rodziną 
(np. Piotrowski [1979: 222-223] czy Adamski [1984: 21], jednak rodzina jest kategorią socjologiczną, a na gruncie nauk ekonomicznych stwierdza się, iż gospodarstwo domowe jest grupą osób spokrewnionych ze sobą lub nie, które wspólnie zamieszkują i dysponują majątkiem, prowadzą wspólne rozliczenia, a także wspólnie dążą do maksymalizacji zaspokojenia potrzeb.

Jak wspomniano powyżej, finanse gospodarstw domowych są częścią obszernej dziedziny, jaką są finanse. Zaś finanse gospodarstw domowych, definiowane również jako finanse osobiste (personal finance), określane są jako dziedzina, która zajmuje się stosunkami ekonomicznymi polegającymi na gromadzeniu zasobów pieniężnych, ale także na ich wydatkowaniu przez członków danego gospodarstwa domowego [Korenik i Korenik 2004: 13]. Bardziej obszerna definicja stanowi, iż finanse osobiste zostały określone jako jedna $\mathrm{z}$ dziedzin nauk ekonomicznych, związana $\mathrm{z}$ gospodarowaniem środami finansowymi przez jednostki stanowiące całość gospodarstwa domowego w zakresie pozyskiwania, a w dalszej kolejności gromadzenia i wydatkowania środków finansowych [Świecka (red.) 2008: 64]. Jednak, niezależnie od przyjętej definicji finansów osobistych, niezmiernie ważny jest aspekt zarządzania tymi finansami. Zarządzanie finansami gospodarstw domowych to wszystkie czynności członków gospodarstwa domowego, które polegają na pozyskaniu, a następnie wydatkowaniu środków finansowych zgodnie z przyjętymi założeniami - celami danego gospodarstwa domowego [Bywalec 2009: 45]. Elementy zarządzania finansami osobistymi, proponowane przez różnych autorów, zaprezentowano w tab. 1.

Tabela 1. Elementy zarządzania finansami gospodarstw domowych

\begin{tabular}{|c|c|}
\hline Autor & Obszar zarządzania finansami osobistymi \\
\hline Cz. Bywalec & $\begin{array}{l}\text { 1. Planowanie finansów osobistych } \\
\text { 2. Zarządzanie majątkiem i kapitałem } \\
\text { 3. Zarządzanie płynnością finansową i budżetem } \\
\text { 4. Zarządzanie oszczędnościami } \\
\text { 5. Zarządzanie ryzykiem z uwzględnieniem bankructwa i upadłości gospo- } \\
\text { darstw domowych. }\end{array}$ \\
\hline S. Flejterski & $\begin{array}{l}\text { 1. Decyzje dotyczące konsumpcji i oszczędności. } \\
\text { 2. Decyzje inwestycyjne. } \\
\text { 3. Decyzje finansowe. } \\
\text { 4. Decyzje związane z zarządzaniem ryzykiem. }\end{array}$ \\
\hline K. Jajuga & $\begin{array}{l}\text { 1. Zarządzanie płynnością. } \\
\text { 2. Długoterminowe decyzje finansowe. } \\
\text { 3. Długoterminowe decyzje inwestycyjne. } \\
\text { 4. Decyzje w zakresie zabezpieczenia kapitały. } \\
\text { 5. Decyzje emerytalne. }\end{array}$ \\
\hline
\end{tabular}

Źródło: opracowanie własne na podstawie Bywalec [2009: 15-18], Flejterski [2007: 82-83], Jajuga [2008: 124]. 
Na potrzeby niniejszego opracowania przyjmuje się, iż zarządzanie finansami osobistymi to całokształt czynności, które leżą po stronie gospodarstwa domowego $\mathrm{w}$ zakresie pozyskania i podziału środków finansowych. Uzupełniając definicję zarządzania finansami osobistymi zaproponowaną przez autorkę, na rys. 1 zaprezentowano elementy zarządzania finansami gospodarstw domowych.

Pozyskiwanie środków finansowych (podejmowanie decyzji w zakresie sposobu i rodzaju zarobkowania).

Realizacja zobowiązań (podejmowanie decyzji w zakresie zaciągania, a następnie spłaty zadłużenia).

Dokonywanie konsumpcji (podejmowanie decyzji w zakresie wydatków bieżących).

Gromadzenie oszczędności (podejmowanie decyzji w zakresie wysokości i rodzaju oszczędności).

Uwzględnianie ryzyka i planowanie (podejmowanie decyzji i działań mających na celu przewidywanie przyszłych zdarzeń oraz ryzyka wystąpienia zdarzeń losowych).

Rysunek 1. Zarządzanie finansami gospodarstw domowych

Źródło: opracowanie własne.

Zarządzanie finansami gospodarstw domowych, jak wskazano, ma bardzo silny związek $\mathrm{z}$ decyzjami $\mathrm{w}$ zakresie finansów. Zarządzanie finansami osobistymi ma charakter uniwersalny - każde gospodarstwo domowe zarówno w kraju jak i za granicą, aby maksymalizować zaspokajanie swoich potrzeb, ale także jak najbardziej efektywnie dysponować domowym budżetem, zobowiązane jest do poddania się procesowi zarządzania finansami gospodarstwa domowego. Przy tym, bardzo ważnym jest na wskazanie różnic oraz podobieństw pomiędzy decyzjami podejmowanymi w poszczególnych krajach europejskich.

\section{FINANSE OSOBISTE W KRAJACH EUROPEJSKICH}

Kryzys finansowy z 2008 roku, odbił się szerokim echem i miał wpływ na każdy podmiot funkcjonujący w gospodarce, $\mathrm{w}$ tym również na gospodarstwa domowe. W wielu krajach Europy, zaobserwowano spadek wysokości dochodu do dyspo- 
zycji. Chcąc zweryfikować, jak różnią się od siebie poszczególne elementy zarządzania finansami osobistymi, w pierwszej kolejności uwagę należy skupić uwagę na dochodzie rozporządzalnym (household's available income) ${ }^{1}$, którego wysokość została zaprezentowana na wykresie 1.

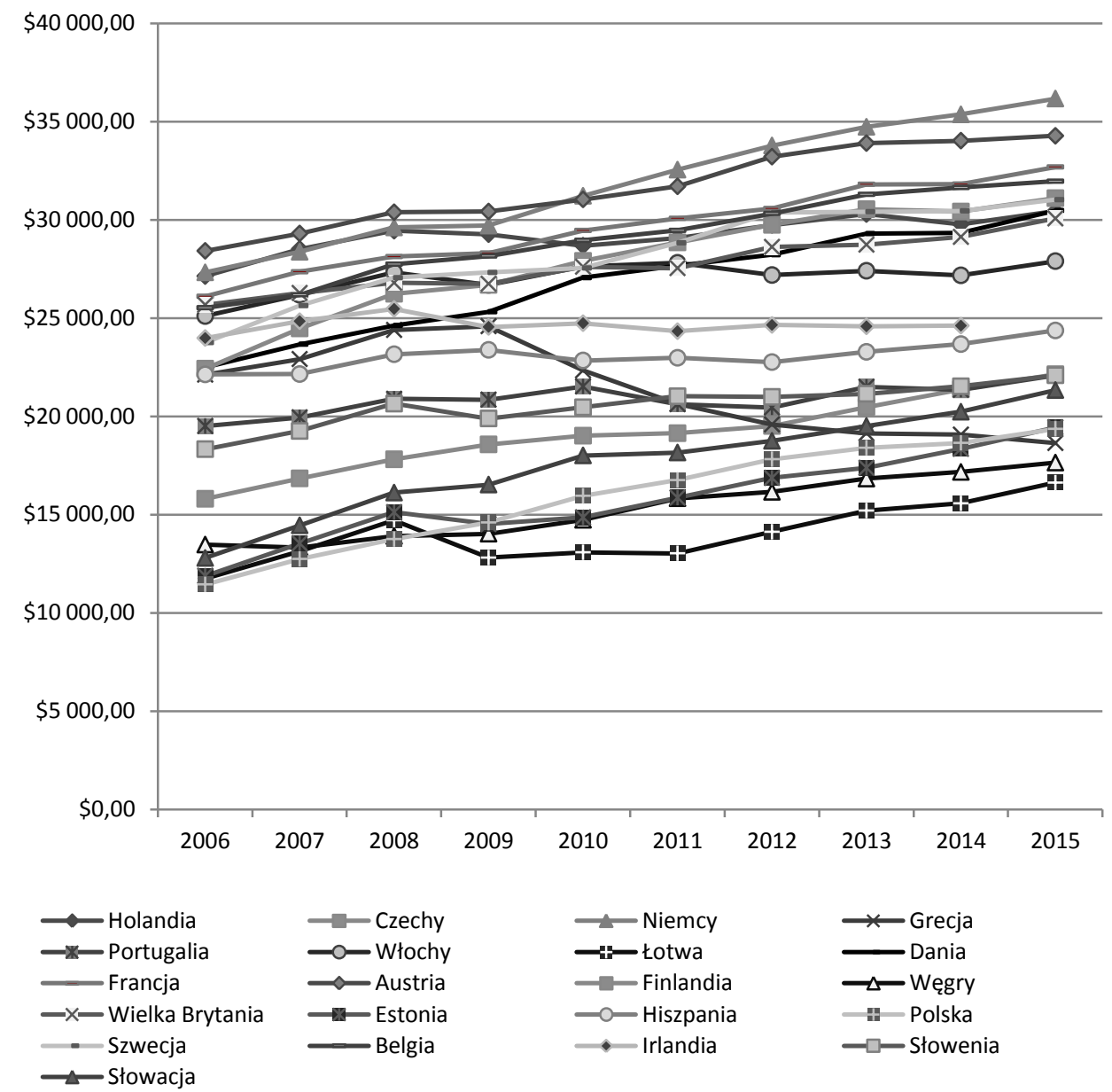

Wykres 1. Dochód rozporządzalny w krajach europejskich

Źródło: opracowanie własne na podstawie danych OECD: https://data.oecd.org/hha/house hold-disposable-income.htm\#indicator-chart [dostęp: 30.01.2017].

${ }^{1}$ Dochód rozporządzalny, czyli dochód z wyłączeniem trwałych obciążeń finansowych o charakterze składkowym i podatkowych; obejmuje w swym zakresie wszystkie pieniężne i niepieniężne dochody gospodarstw domowych w określonym czasie [Budżety gospodarstw domowych w 2010 roku, 2011: 16]. 
Rzeczywisty dochód gospodarstwa domowego definiowany jest jako suma płac - dochodu netto, czyli przychodu pomniejszonego o podatki dochodowe oraz składki na ubezpieczenie społeczne. Prezentowany wskaźnik mierzony jest w ujęciu rocznym. Od początku badanego okresu, Austria charakteryzuje się najwyższym poziomem dochodu rozporządzalnego - tendencja ta utrzymuje się do 2009, zaś od roku 2010 Niemcy wiodą prym w zakresie wysokości dochodu rozporządzalnego gospodarstw domowych. Kolejne z państw, które charakteryzują się wysokim poziom to Francja, Belgia oraz Holandia. Z roku na rok, zauważalna jest poprawa dochodu w przypadku Szwecji (o 7274,16 \$ od roku 2006 do 2015), Finlandii oraz Dani. Wśród krajów wymienić można te, które od początku badanego okresu, charakteryzują się bardzo niskim poziomem dochodu rozporządzalnego: Łotwę, Estonię oraz Polskę - dochód rozporządzalny wynosi mniej niż 12000 \$. Jednak, zarówno w przypadku wymienionych krajów o najwyższym, jak i najniższym poziomie dochodu rozporządzalnego obserwuje się trend wzrostowy. Odstępstwem od tej zasady jest Grecja. W przypadku tego państwa, dochód rozporządzalny stopniowo zmniejsza się. Poziom dochodu rozporządzalnego w Grecji w 2006 roku osiągnął 22 125,03 \$, zaś najwyższy odnotowano w 2009 (24 590,21 \$). Jak wspomniano, z roku na rok, dochód rozporządzalny maleje - w 2015 r. przyjął wartość 18 644,03 \$ i jest to najniższa, dotychczas odnotowana wartość. Dochód rozporządzalny, jak wskazano w poprzedniej części pracy, jest dochodem w pełni pozostającym do dyspozycji gospodarstw domowych. Posiadając określoną wartość dochodu rozporządzalnego, gospodarstwa domowe mogą decydować na jakie cele przeznaczą te środki - jaka część zostanie zaoszczędzona, skonsumowana czy też przełożona na realizację zobowiązań.

Znając poziom dochodu, jaki w danym roku pozostaje do dyspozycji gospodarstw domowych, należy zwrócić się w kierunku innych elementów finansów gospodarstw domowych, które zależą od zarządzania finansami. Poniżej zaprezentowano procentowy udział zobowiązań gospodarstw domowych w ich dochodzie rozporządzalnym. Zwrócić należy uwagę, iż wysokość zobowiązań ma duży związek z osiąganymi dochodami - im dochody wyższe, tym udział zadłużenia również wyższy (przykład Holandii, Danii). Dodatkowo, w przypadku niektórych państw, udział długu zdecydowanie przewyższa wysokość osiąganego dochodu rozporządzalnego - nawet trzykrotnie.

Zadłużenie gospodarstw domowych definiowane jest jako zbiór wszystkich zobowiązań, które wymagają zapłaty (wpłaty), odsetek lub kwoty głównej przez gospodarstwa domowe wobec wierzycieli w określonej dacie (datach), w przyszłości. W odniesieniu do gospodarstw domowych, zobowiązania dotyczą przede wszystkim kredytów i pożyczek, w tym również kredytów hipotecznych na zakup mieszkania czy domu. Prezentowane zadłużenie określane jest jako procentowy udział zobowiązań w dochodzie rozporządzalnym. Krajem, który charakteryzuje 
się najwyższym udziałem długu w dochodzie gospodarstwa domowej jest Dania. Średni procentowy udział zobowiązań w dochodzie rozporządzalnym gospodarstw domowych wynosi 316,50\% (najniższy wskaźnik w roku 291,96\% w roku 2015, zaś najwyższy w $2008-339,78 \%)$.

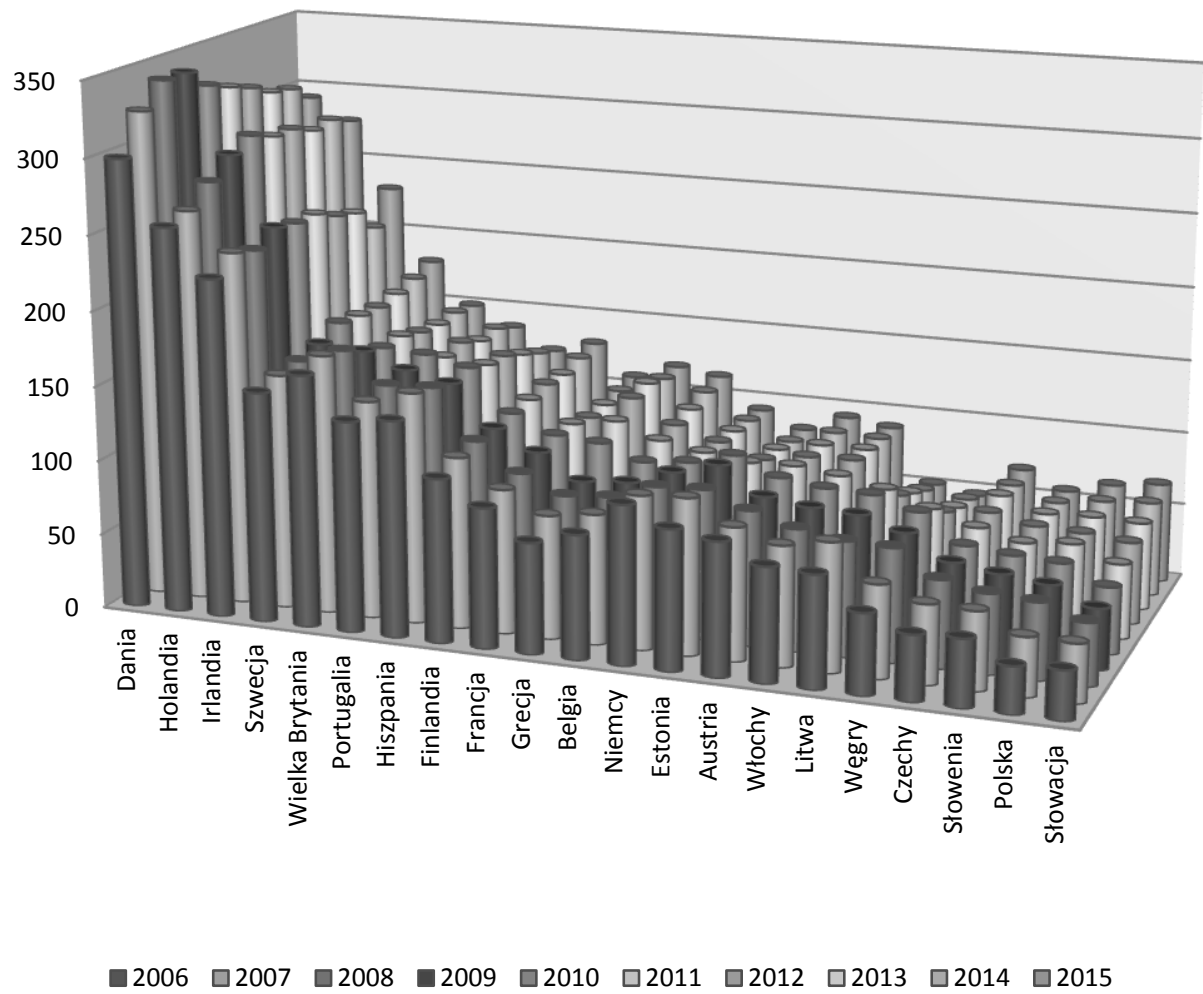

Wykres 2. Zobowiązania gospodarstw domowych - procentowy udział w dochodzie rozporządzalnym

Źródło: opracowanie własne na podstawie danych OECD: https://data.oecd.org/hha/house hold-debt.htm\#indicator-chart [dostęp: 01.02.2017].

Wśród wskazanych krajów istnieją takie, w przypadku których procentowy udział zadłużenia w dochodzie rozporządzalnym, maleje z roku na rok. Do tych krajów zaliczyć można Wielką Brytanię, Portugalię, Hiszpanię, a także Niemcy, Estonię, Litwę oraz Węgry. Z drugiej zaś strony, wymienia się Państwa, które początkowo charakteryzowały się bardzo małym udziałem zadhużenia w docho- 
dzie rozporządzalnym, ale z roku na rok udział ten stale rośnie (Szwecja, Polska, Słowacja, Czechy, Austria, Belgia, Grecja, Francja oraz Finlandia). Najwyższy udział zadłużenia w dochodzie rozporządzalnym odnotowuje się w roku 2010, zaś najmniejszy w 2006. Przy analizie zadłużenia jako procentowego udziału w dochodzie rozporządzalnym, należy zwrócić szczególną uwagę na to, iż wskaźnik ten jest bardzo wysoki. Średnia wskaźnika ze wszystkich lat oraz wszystkich państw wynosi 123,30\%, co oznacza, że zadłużenie gospodarstw domowych zdecydowanie przewyższa dochód rozporządzalny. Jak wspomniano, najwyższym odsetkiem zadłużenia charakteryzuje się Dania, ale w Holandii również procentowy udział zadłużenia jest bardzo wysoki (w 2010 r., wskaźnik ten osiągnął poziom $294,18 \%$ i był najwyższy spośród wszystkich badanych lat w tymże kraju). W przypadku Polski, Słowacji i Czech na początku badanego okresu (2006 r.), udział zadłużenia był najniższy - odpowiednio dla Słowacji 32,59\%, dla Polski $31,35 \%$ oraz dla Czech 43,64\%. W przypadku tych trzech państw, z roku na rok udział zadłużenia stale rośnie (w roku 2015 wskaźnik dla Słowacji wyniósł 67,99\%, dla Polski 64,18\% i dla Czech 68,68\%). Ciekawy trend obserwuje się w przypadku Słowenii - w 2006 r., udział zadłużenia w dochodzie rozporządzalnym wyniósł $44,88 \%$, po czym regularnie wzrastał. Najwyższy poziom osiągnął w 2012 r. (59,71\%), jednak od tego czasu stopniowo maleje (w 2015 r. 56,71\%).

Według OECD, oszczędności gospodarstw domowych definiowane są jako różnica między dochodami, a wydatkami konsumpcyjnymi. Wskaźnik tek określony jest jako procent dochodów do dyspozycji gospodarstw domowych.

Pierwszą teorię na temat oszczędzania skonstruował John Keynes. Według niego, ludzie posiadają stałą skłonność do konsumpcji, a różnica między dochodem a wydatkiem konsumpcyjnym stanowią oszczędności. Zgodnie z tą ideą, stopa oszczędności powinna być tym wyższa, im wyższe dochody otrzymuje dane gospodarstwo domowe. Jednak, w rzeczywistości Keynes nie miał racji, ponieważ wydatki konsumpcyjne rosną niemalże całkowicie razem $\mathrm{z}$ dochodem. Zwrócić należy także uwagę na teorię Modiglianiego, który to twierdził, że gospodarstwa domowe dążą do stałego poziomu konsumpcji w ciągu całego życia. W tym przypadku, można podać przykład młodych ludzi, którzy nie zarabiają zbyt dużo, ale przy tym zaciągają kredyty na zakup dóbr trwałego użytku. Zgodnie $\mathrm{z}$ tą zasadą, wydatki przewyższają dochody, więc oszczędności przyjmują wartość ujemną. Na wykresie 3, zaprezentowano udział oszczędności w dochodzie gospodarstw domowych.

W przypadku oszczędności gospodarstw domowych, mają one zdecydowanie mniejszy udział w dochodzie niż zobowiązania. Kraje, które charakteryzowały się najwyższym udziałem oszczędności w dochodzie to Szwecja (12,80\%), Niemcy (9,76\%), Francja (9,56\%), a także Austria (9,37\%) 


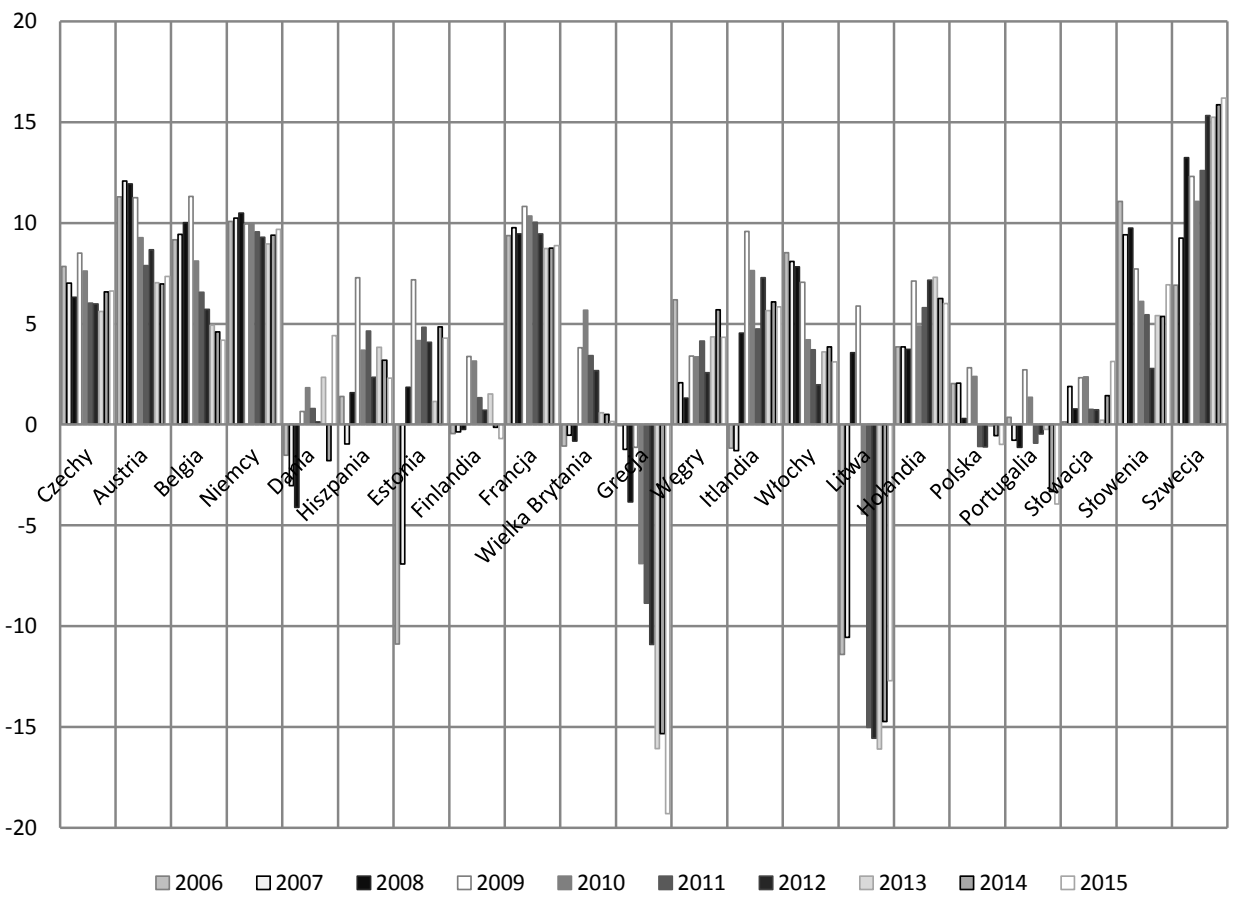

Wykres 3. Udział oszczędności w dochodzie gospodarstw domowych

Źródło: opracowanie własne na podstawie danych OECD: https://data.oecd.org/hha/house hold-savings.htm\#indicator-chart [dostęp: 08.02.2017].

Na przestrzeni badanych lat, znalazły się państwa, w których stopa oszczędności charakteryzowała się wartością ujemną. Najniższe oszczędności należą do gospodarstw domowych z Litwy oraz Grecji. Zaskakującym jest to, że najwięcej oszczędności odnotowuje się w 2009 r. (a więc w rok po zaistnieniu ogólnoświatowego kryzysu finansowego). Jednak, od tego czasu - od momentu osiągnięcia oszczędności w najwyższych wartościach, udział oszczędności w dochodzie gospodarstw domowych, stale maleje. Wyjątkiem jest rok 2015, w których udział oszczędności w dochodzie był wyższy niż w 2014 - trend malejący został przerwany. Wskazać należy również, iż występuję trudność w określeniu trendu (malejącego lub rosnącego), w przypadku wszystkich państw. W przypadku Belgii, obserwuje się stałą tendencję malejącą. Zaś, w przypadku Szwecji jednoznacznie można wskazać na rosnący udział oszczędności w dochodzie. Średni udział oszczędności w dochodzie gospodarstw domowych, wszystkich państw w okresie od 2006 do 2015 r., wynosił 3,45\%. 


\section{PODSUMOWANIE}

Problem z precyzyjnym określeniem definicji gospodarstwa domowego, a także zarządzania finansami gospodarstw domowych rodzi wiele problemów z punktu widzenia teoretycznego. Jednak, na gruncie opracowań literaturowych, wywnioskować można pewne cechy, które powielają się w tychże definicjach. Gospodarstwa domowe zarządzają swoim budżetem tak, że podejmują określone decyzje, które w konsekwencji wiążą się z rozdysponowaniem dochodu. Decyzje te dotyczą głównie zobowiązań (kredytów), a także oszczędności. Większość europejskich gospodarstw domowych posiada roczne zobowiązania, które zdecydowanie przewyższają ich dochody. Zupełna odwrotność charakteryzuje oszczędności, które określone jako udział w dochodzie gospodarstwa domowego, stanowią wręcz minimalny odsetek. Zgodnie z celem, w treści wskazano teoretyczne ramy pojęcia zarządzanie finansami gospodarstw domowych. Dodatkowo, zostaje potwierdzona hipoteza dotycząca udziału oszczędności w dochodzie rozporządzalnym. Kraje, które uzyskują wysoki poziom dochodu rozporządzalnego, charakteryzują się również wysokim udziałem oszczędności (np. Niemcy, Austria). Zaś w przypadku, kiedy gospodarstwa domowe, których zobowiązania stanowią duży odsetek dochodu rozporządzalnego lub nawet go przewyższają, oszczędności przyjmują wartości ujemne (np. Dania, Grecja).

\section{BIBLIOGRAFIA}

Adamski F., 1984, Socjologia matżeństwa i rodziny. Wprowadzenie, PWN, Warszawa.

Budżety gospodarstw domowych w 2010 roku, 2011, Informacje i Opracowania Statystyczne, GUS, Warszawa.

Bywalec Cz., 2009, Ekonomika i finanse gospodarstw domowych, Wydawnictwo Naukowe PWN, Warszawa.

Flejterski S., 2007, Metodologia finansów. Podręcznik akademicki, PWN, Warszawa.

Jajuga K., 2008, Nowe tendencje w zarządzaniu finansami osób indywidualnych, [w:] P. Kapuś, J. Węcławski [red.], Rynek finansowy. Inspiracje z integracji europejskiej, Wydawnictwo Uniwersytetu Marii Curie-Skłodowskiej, Lublin.

Korenik D., Korenik S., 2004, Podstawy finansów, PWN, Warszawa 2004.

Pałaszewska-Reindl T., Michna W., 1986, Gospodarstwo domowe - ekonomiczna i organizacyjna baza rodziny polskiej, [w:] T. Pałaszewska-Reindl (red.), Polskie gospodarstwa domowe: życie codzienne w kryzysie, Instytut Wydawniczy Związków, Warszawa.

Piotrowski J., 1979, Spoleczne problemy rodziny, [w:] Polityka spoleczna, PWE, Warszawa.

Samuelson P., Nordhaus W., 2005, Ekonomia 1, PWN, Warszawa.

Światowy G., 2012, Gospodarstwo domowe jako kreator przemian społecznych i gospodarczych, [w:] Konsumpcja i rozwój, nr 2, IBRKK, Warszawa.

Świecka B. (red.), 2008, Bankructwa gospodarstw domowych. Perspektywa ekonomiczna i spoteczna, Difin, Warszawa.

[www1] https://data.oecd.org. 


\title{
SELECTED FINANCIAL HOUSEHOLDS MANAGEMENT PROBLEMS IN THE EUROPEAN COUNTRIES
}

\begin{abstract}
Households are different in management of their money. Some households spend most of their income for everyday consumption. But, some spend their money on savings and investment. Management of personal finances (household finances), is connected with decisions on available budget to realize the household goal (i.e. maximizing the satisfaction of needs). The article is about financial decisions on indebtedness and savings and showing differences between them in European countries.
\end{abstract}

Keywords: household, debt, saving. 